\title{
FORMS AND METHODS OF TECHNOLOGIES TRANSFER ADJUSTING IN UKRAINE
}

\section{Manylich Mychailo Ivanovich}

Private Higher educational establishment "Bukovyna University", Economic faculty, Department of account and audit, Darvina street, 2-A, 58000, Chernivtsi city, Ukraine

\section{Likholet Sergei Ilyich}

Kyiv national economic university under name of Vadym Get'man, Faculty of

international economy and management, Department of international finances

Peremogy boulevard, 54/1, 03057, Kiev city, Ukraine

\section{(C) MESTE NGO}

JEL category: N0, N7, O3, O34

\section{Summary:}

The paper dwells on basic forms and methods of government control of technologies transfer in Ukraine have been generalized: organizational forms are branches, joint ventures, "turn-key" business, technological universities, partnership, research alliances; economic forms are licensing, sale of intellectual property, including patents and trade secrets, franchising, contract researches. The following basic methods of technologies transfer in Ukraine have been exposed: forsite, technological prognostication with use of Delfi-method, method of critical technologies, development of scenarios, travelling flowsheet, technological corridor and forming of expert panels.

The list of normative legal acts of Ukraine concerning government control of technologies transfer in Ukraine has been given.

\section{Keywords:}

technologies transfer, form, methods, institutional providing, joint ventures, partnership, franchising, Delfi-method

\footnotetext{
The address of the corresponding author:

Manylich M.I.

拝”= vyklyuk@ukr.net
} 


\section{INTRODUCTION - TECHNOLOGIES TRANSFER HYPOTHESIS}

Technologies transfer is one of basic elements of the national innovative system coming from its role and place in the system of industrial politics and industrial right. Essence and maintenance of technologies transfer represent the processes of new knowledge (technologies) transmission from the stage of scientific development to applying in the real industry.

The institutional providing of organizationallyeconomic mechanism of technologies transfer adjusting includes: the Commercial code of Ukraine (Commercial code of Ukraine: article 2065, 2009), "About investment activity" (Law of Ukraine "On investment activity": Article 257, 2009), "About scientific and scientific-technical activity" (Gov., 2008), "About scientific and technical information" (UA Gov, 2004), "About scientific and scientific-technical examination" (UA Gov, 2006), "About the dedicaded mode of innovative activity of technological parks" (UA Gov, Law of Ukraine "On the dedicaded mode of innovative activity of technological parks": article 182, 2006), "About priority directions of science and technology" (UA Gov, A law of Ukraine "Law of Ukraine "On priority directions of development of scitech": article 199, 2006), "About innovative activity" (2005), "About priority directions of innovative activity in Ukraine" (UA Gov, Law of Ukraine "On priority directions of innovative activity in Ukraine": article 219, 2008), "About the national complex program of development of scientifically high-tech" (UA Gov, Law of Ukraine "On the National complex program of development of scientifically high-tech" , 2004), "About government control of activity in the field of the transfer of technologies" (UA Gov, Law of Ukraine "On government control of activity in the field of the transfer of technologies" №1436 - V, 2006).

The law in Ukraine is examined as the normatively-legal act accepted by the supreme legislative body of country in the set constitutional order; has higher legal force in relation to other normative acts and is obligatory for implementation by all physical and legal persons (Korel'skiy \& Gavrilov, 2000).
A decree in Ukraine is the name of the most essential acts that are signed by yhe head of the state (by a president). (Sukharev \& Krutskih, 2002) One of types of legal acts, that President of Ukraine gives out, is the basic type of the real acts and divided into legislative Decrees and administrative (from practice of application of terms, words and word-combinations in jurisprudence).

The legal providing of transfer of technologies is formed by such Decrees of President of Ukraine, as: "About events in relation to the use of space technologies for innovative development of economy of the state" (President UA, 2001), "About the decision of national security and defensive Council of Ukraine from July, 3, 2001 "About urgent events in relation to a overcoming the crisis state of scientifically-technological sphere of Ukraine and creation of the real terms for passing of economy to the innovative model of development" (Decree, 2001), "About sponsorship of innovative activity of enterprises that have a strategic value for an economy and safety of the state" (Decree, 2004), "About the decision of national security and defensive Council of Ukraine from April, 6, 2006 "About the state of scientifically-technological sphere and events in relation to providing of innovative development of Ukraine" (Decree, 2006).

Resolution of Government as constituent of the legal providing of organizationally-economic mechanism of technologies transfer adjusting is to be as follows :1) a normative act of legislative government power - Supreme Council of Ukraine - on organizational questions; 2) normative act of supreme body of executive power - to Cabinet of Ministers of Ukraine - on general problems, problems of economy, industrial politics, education, culture and others like that (from practice of application of terms, words and wordcombinations in jurisprudence).

To resolutions of Cabinet of Ministers of Ukraine, that form the legal field in the sphere of transmission of technologies, it is expedient to take the following: "About creation of the State innovative fund" (Resolution, 2000), "About confirm of Statute about the order of creation 
and functioning of technoparks and innovative structures of other types" (Resolution, 2004, p. 1), "About formation of the Ukrainian state innovative company" (Resolution, 2007), "About confirm of Order of forming, examination and discussion of priority directions of innovative activity" (Resolution, 2004, p. 182), "About confirm of State registration order of innovative projects and the State register of innovative projects conduct " (Resolution, 2003, p. 42), "About confirm of Sponsorship grant order the subjects of innovative activity due to money of the state budget by reduction of prices of longterm credits" (Resolution, 2004, str. 68), "About events in relation to support of innovativeinvestment projects" (Resolution, 2003, p. 413), "About confirm of monitoring and control realization of technological parks projects order" (Resolution, 2007, str. 49), "About confirm of Order of realization of state accreditation of physical and legal persons on realization on permanent and/or professional basis of intermediary activity in the field of the transfer of technologies" (Resolution, 2009), "Some questions of realization of Law of Ukraine "About government control of activity in the field of the transfer of technologies" (Resolution, 2007), "About confirm of minimum rates of reward to the authors of technologies and persons that carry out their transfer" (Resolution, 2008).

To Cabinet of Ministers of Ukraine Orders, that touch the problems of the technologies related to the transfer belong the following: "Question of formation of regional centers of innovative development" (Order, 2007), and "About the transmission of Department of education and science of plenary powers" (Order, 2008). Here the order is to be considered as a bylaw management, that is issued by the leader of organization on operative and other questions, in the individual order, and has obligatory force for subjects that it is addressed to (from practice of application of terms, words and wordcombinations in jurisprudence).

In turn, an order is a prescriptive legal act that is issued by a management organ, operating on the basis of undivided authority, for the solving of basic in operative tasks that stand before this organ (Anon, 2001).
The transfer of technologies in Ukraine is regulated by the following Orders: Ministry of education and science of Ukraine Order "About confirm of "Statute about the order of realization of monitoring of innovative projects implementation on priority directions of technological parks activity" (Order, 2005), Ministry of education and science of Ukraine Order "About confirm of Order of state registration of agreements on the technologies transfer and the State register of agreements on the technologies transfer conduct " (Order, 2008), An order of Ministry of industrial politics of Ukraine "About confirm of Order of competitive selection of the innovative and investment projects directed on creation and applying of modern technique in industry in the field of an aircraft construction and space industry" (Order, 2007).

\section{THE ORGANISATION FORMS OF TECHNOLOGIES TRANSFER ANALYSIS IN UKRAINE}

One of the basic organizational forms of transfer of technologies there is a branch of foreign company in Ukraine. This form is related to the direct foreign investments and envisages the hundred-per-cent possessing of the company's assets by an international corporation.

According to the article 95 of the Civil Code of Ukraine (2009) a branch is a separated subdivision of legal entity that is situated out of its location and carries out all or part of its functions. Branches and representative offices are not legal entities, they are provided with property of legal entity to have created them, and operate on the basis of the position ratified by this legal entity. The leaders of branches and representative offices are appointed by a legal entity and operate on the basis of its given warrant. (UA Gov, 2009)

The next organizational form of transfer of technologies in Ukraine are joint ventures enterprises that are based on the general capital of subjects of economic activity of Ukraine and foreign subjects of economic activity, on a general management and on general distribution of results and risks (UA Gov, 2009, str. 42).

International joint ventures can be based on a contract and also on property. They are, in turn, 
classified by part of property of an international corporation that can be basic, equal and insignificant.

Another organizational forms of transfer of technologies in Ukraine is the creation of "turnkey" business that is a type of enterprise activity where are created all necessary pre-conditions in order to begin doing business immediately. It is a form of the ready business that includes material resources (inventory and equipment) and non-material assets, such as business reputation had been created before. The most widespread type of such form of enterprise is a franchise (Ward, 2012).

However, if to examine "turn-key" business in the context of innovative products creation, then it follows to underline that innovations can not be a serial product. And thus this form of technologies transfer should be examined exactly as an innovative project that envisages going into a market with a new product that does not have analogues, and in the moment of going into a market, creates a new niche.

Higher educational establishments (HEE), as a rule technological universities of Ukraine, become basis for creation of new enterprises in the form of "turn-key business". An idea consists in that this decides at once a few problem questions.

Firstly, an enterprise is created for going into a market with an innovative product that must satisfy demand that exists in the market for hitech products.

Secondly, specialists that will form the labour collective of the marked enterprise are prepared within the framework of this HEE. At once the problem is finding its solution both in highly qualified staff search, which is to have preparation exactly for the successful realization of such projects, and youth employment after graduation.

Thus, within the framework of such projects activity realization of technological university is not limited to knowledge generating, but also their practical use orientation by means of new products creation competitive both on home and foreign markets.
The transfer mechanism of technologies in Ukraine includes also partnership or strategic alliance. Thus agreements are made between companies about a collaboration that go beyond the scopes of ordinary business relationships between enterprises, but does not envisage confluence, absorption or creation of complete society.

The form of long-term cooperation of enterprises is used with the aim of co-ordination of productive and market activity for the achievement of stable perspective advantages on the market. As a rule, it is a collaboration, an alliance of one company with other, bigger and mightily in a financial relation that can provide resources for the some economic and strategic aims achievement (Lozovskiy, Raizenberg, \& Ratnovskiy, 1997).

Research alliances on the basis of agreements on realization of mutual scientific researches are created without formation of new legal entity. Such structures are formed on the stage of commercialization of technology and broken up after gaining aim. This form is the most widespread mechanism of participants' efforts combination of transfer and technologies commercialization.

\section{THE ECONOMIC FORMS OF TECHNOLOGIES TRANSFER ANALYSIS IN UKRAINE}

In Ukraine the technologies transfer mechanism, besides organizational ones, includes the number of economic forms. One of the main is intellectual property licensing or sale, including patents and trade secrets. A license agreement is the form of contract between two organizations that determines a transmission from one side of agreement to other an exclusive or unexclusive right to use intellectual property that belongs to this side.

The transfer of technology takes place then, when the proprietor of intellectual property (technologies) passes to other side necessary data and legal right on the complete use of this technology in an exchange payment in a that or other form, in particular, including royalty. The recipient of license can stipulate his right to pass to a sub-lisence to other parties also. In case of 
sale of intellectual property a salesman passes all rights on it to the customer.

The next form of organizationally-economic mechanism of adjusting of transfer of technologies in Ukraine is "franchising" - the entrepreneurial activity according to which contractual basis one side (franchiser) passes to other side for a reward on a certain term or without pointing of such: right for the use of trade mark; sign of service; brandname (trade) name; services; technological process; specialized equipment; now-how; commercial information that is guarded by a law; other, by the envisaged agreement of objects of right of intellectual ownership (Tsyrat \& Krivonos, 2004).

And however on the modern stage of a contract collaboration is the basic economic form of mechanism of technologies transfer adjusting.

Contract research-and-developments are the form of "acquisition" of service of one company by the other. In industry of high-tech there are hundreds of the specialized research companies that render similar services. In this form of collaboration a contractor, as a rule, renounces rights on intellectual ownership of the product of researches.

In Ukraine they distinguish such forms of contract collaboration as: contract production with technical support; administrative contract; contract of studies; consulting contract; contract of research-and-developments; architectural and engineering contract; contracts of management building and others.

The following among the economic forms of technologies transfer is the financial leasing (further is leasing) as type of civil legal relations that arise out of agreement on the financial leasing. By agreement on the financial leasing (further is a leasing agreement) - leasing-giver is obligated to purchase in property thing from a salesman (supplier) in accordance with the set leasing-recipient specifications and terms and to pass in the use of leasing-recipient on a certain term not less than one year for the set pay (leasings payments).

\section{THE TECHNOLOGIES TRANSFER METHODS ANALYSIS IN UKRAINE}

\subsection{Forsight}

One of basic methods of transfer of technologies in Ukraine is "foresight". It is the system of methods of expert estimation of long-term prospects of innovative development, exposure of technological breaches capable most positively to influence on an economy and society. That is a strategic priorities of state, region, industries or companies development choice which are based on innovations and are directed to the increase of competitiveness of national economy.

Due to the foresight use the scale national and international research programs are formed. Among them, in particular, Seventh Scope programme on scientific researches and technological development of EU (2007-2013), the budget of that made 54 milliards of euro (Anon, 2012).

On the basis of foresight the long-term, on 25-30 years, strategies of development of economy, science, and technologies are developed that are aimed at the increase of competitiveness and maximally effective development of socioeconomic sphere. In the process of foresight the possible scenarios of development of separate directions of science and technologies are estimated, potential technological vectors are determined.

\subsection{Technological forecasting}

The next method that is included in the complement of organizationally-economic mechanism of adjusting of transfer of technologies is prognostication.

Technological prognostication in Ukraine is considered as a process, during which the prospect of change of consumer qualities of wares, technological processes and equipment, and also adequate changes in charges on a production are determined (Raizenberg, Lozovskiy, \& Starodubtseva, 2006).

The most popular approaches to technological prognostication are: the use of Delfi-method and method of critical technologies, development of scenarios and travelling flowsheet, and also 
forming of expert panels and technological corridors.

Delfi-method is questioning the plenty of experts, to 2-3 thousands, and organization of backconnection (through realization of the second tour of questioning). This method assumes the selection of highly skilled experts, creation of expert panels on separate directions of science and technologies; development of list of themes - the potential scientifically-technological achievements expected in long-term prospect (25-30 years), including fundamental and applied researches, innovative goods and services that are created on the basis of new technologies.

Experts estimate actuality of every theme for development of economy, society, presence of resources and potential barriers to practical realization. Research results include the erected estimations on every topic, and also analitical reviews on major directions of science and technologies (Sokolov, 2007).

The aim of the use of method of critical technologies is an exposure of priorities of scientific and technical development on a medium-term prospect. This approach is used not only at the level of the country on the whole but also of the separate industries of economy, thematic areas, or regions.

The list of critical technologies is formed on the basis of knowledge of experts that own the greatest qualification in corresponding areas.

For participating no more than 200 experts are attracted in a project, but term of prognostication is to be from 5 to 10 years.

As a rule, the lists of technologies or directions of research-and-developments that require nearterm attention become a result (Sokolov, 2007). An additional document - "passport" is prepare for every critical technology, where the areas and sphere of potential additions are included and briefly described, and also the possible terms of practical realization are estimated and the events of state support are offered (Sokolov, 2007, pp. 64-74).

The previous list of critical technologies is formed on the basis of the expert questioning and interviews. Then the list comes into discussion within the framework of the special panels and focus groups in the process of which the final selection and concordance of list of critical technologies is realized.

A "standard analysis"(benchmarking) is sometimes used, i. e. comparing to other countries or regions, that allows not only to define the level of development of technology in a country, region or industry but also correlate it with the level of world leaders, to educe the degree of lag and work out strategy of acceleration of technological development in sectors with most innovative potential. A primary purpose of estimation of critical technologies is an increase of competitiveness of economy and decision of major social problems (Sokolov, 2007).

Development of scenarios includes creation of scenarios of development of those or other technological spheres. Scenarios are created on principle "from below to top" or "from top to bottom" and are based on the analysis of future possibilities and alternative trajectories of development (Sokolov, 2007).

Scenarios are most effective as adding to the researches executed on the basis of other methods - SWOT - analysis (estimations of strengths and weaknesses, possibilities and risks), cerebral assaults, biblemetrical and patent analysis (Sokolov, 2007).

Scenarios describe basic moving forces in the certain pictures of the future and their connection between each other. They expose also different possible ways of development as alternative pictures of the future. In a result there is more exact understanding of prospects of development, existent possibilities and limits of solving of problems (Minks \& Bel'kne, 2008).

The method of expert panels is considered basic and often used for development of strategies of development. The groups of experts from 12-20 persons are offered during a few months to calculate the possible variants of the future on the set subjects, using the newest analytical and informative materials and developments. The basic advantages of this method is a presence of experts during all process of work, cooperation between the representatives of different scientific 
disciplines and areas of activity that it is difficult to organize in other conditions.

This method can complement other approaches. In some cases creation of panels is needed for development of going out information, interpretation of the acieved results or application of method on the whole.

A travelling map (Technology Roadmap) was worked out at the end of 70th by a company Motorola and in Ukraine is used for development of long-term strategies of development of technologies of industry or large company.

The essence of method lies in organizations of the strategic planning, to which experts that present basic component business are brought over, - marketing, finances, productive infrastructure, technologies, research-anddevelopments. A "Road map" illustrates the transition stages from current status to the phases of development in a long-term prospect due to synchronous development of technologies, products, services, business and market.

The basic advantage of method is forming of the concerted positions in relation to the long-term aims of development of industry or company.

Technological Road map, as an instrument of the strategic planning, allows organizations to prepare to the changes and score advantages from new possibilities. For enterprises it means identification of market tendencies and demand for new products, and make a choice of technology necessary for their production at adequate price level.

Technological Road maps provide two basic advantages. Firstly, the process of their preparation allows the enterprise to estimate threats and possibilities, define priorities and, secondly, integrate major factors (market demand, requirements of consumers, level of competition, technology of production, development of new products, financial management) in a successive strategic plan.

A technological map assists the exposure of bottlenecks (a lack of capital, low technological potential, breaks, in the chains of deliveries) that must be "overcome", and specification of priorities, in the field of investments, selection of staff, research-and-developments.

Technological corridors are a list of obligatory requirements and limitations, that are given to the technical parameters of technologies, consumer products and services, set by the state, with laying out on years and gradual increase of their inflexibility. Such system is built on technical regulations and standards and presents itself the chain of the interdependent limitations directed to the change of technological level of corresponding industry. With application of these standards, the state not only reduces power-hungryness of home economy but also motivates producers to the collaboration with the developers of NT, and also forms powerful long-term demand for their services.

\section{CONCLUSIONS}

Thus, penetration of new scientific ideas, technique, technology in Ukraine is not provided automatically. Bringing of new directions of scitech in the system of state administration requires the use of adequate principles, mechanisms, conception of realization of new ideas in economic turnover. In turn, changes in the system of state administration socioeconomic development on the basis of introduction of scientific and technical progress suppose the development of the corresponding institutional providing.

The last structural component of organizationally-economic mechanism of adjusting of transfer of technologies in Ukraine is a dataware that includes the following key elements as: report and operative data of enterprises; statistical on-line data; normative and instructional information of all levels (state, regional, branch); planned-prognosis information; certificate-analytical information. It is necessary also to mark that information must be clearly structured, thus each of the abovementioned elements must be associated. Information of more subzero level (initial), for example, microeconomic indexes, is an entrance for a higher level, regional level (branch, region), i. e. it will be an entrance for a higher level (macroeconomy). 
This block is especially important, as modern Ukrainian society is oriented to information (informative society). Accordingly, an orientation on creation of economy of front-rank knowledge is the main key point for the successful functioning and development of socio-economic systems.

\section{WORKS CITED}

Anon. (2001). Management by organization: Encyclopedic dictionary. INFRA-m.

Anon. (2012). Delegation to Russia. Retrieved from Delegation of the European Union to Russia: http://www.delrus.ec.europa.eu/ru/images/pText pict/694/FP7\%20background\%20RU.doc

Decree. (2001). Decree of President of Ukraine "About the decision of national security and defensive of Ukraine Council from July 3, 2001. Official announcer of Ukraine(34), 33.

Decree. (2004). A decree of President of Ukraine "About sponsorship of innovative activity of enterprises that have a strategic value for an economy and safety of the state" from 20.04.2004 №454/2004 - article 10. Official announcer of Ukraine, 109.

Decree. (2006). Decree of President of Ukraine "About the decision of national security and defensive of Ukraine Council from April, 6, 2006 "About the state of scientifically-technological sphere and events in relation to providing of innovative development of Ukraine"'. Official anouncer of Ukraine(28), 12.

Gov., U. (2008, 05 22). Law of Ukraine "On scientific and scientific-technical activity" . The Official announcer of Ukraine: article 1272(38), 22.

Korel'skiy, V., \& Gavrilov, R. (2000). M: international relations. In V. Korel'skiy, \& R. Gavrilov, Exchange dictionary: In 2 volumes. (Vol. 1, p. 288).

Lozovskiy, L., Raizenberg, B., \& Ratnovskiy, A. (1997). Universal business-dictionary. M.

Minks, E., \& Bel'kne, E. (2008). To think the categories of the multiple future . Forsite, 8(4), 4-8.

Order. (2005). Order METAL-OXIDE-SEMICONDUCTOR Ukraine "About claim of "Statute about the order of realization of monitoring of implementation of innovative projects after priority directions of activity of technological parks"': by the state on 18.12 .2005 article 3140 . Official announcer of Ukraine(50), 62.

Order. (2007). An order of Ministry of industrial politics of Ukraine "About claim of Order of competitive selection of the innovative and investment projects sent to creation and applying in industry of modern technique in the field of an aircraft construction and ...". Offical anouncer of Ukraine(21), 30.

Order. (2007). Order of Cabinet of Ministers of Ukraine "Question of formation of regional centers of innovative development" from 03.05.2007 № 255-r - article 1346. Official announcer of Ukraine(33), 44.

Order. (2008). Order METAL-OXIDE-SEMICONDUCTOR Ukraine "About claim of Order of state registration of agreements on the transfer of technologies and conduct of the State register of agreements on the transfer of technologies" from 14.05.2008 № 409 - article 1313. Official announcer of Ukraine(39), 85.

Order. (2008, 02 13). Order of Cabinet of Ministers of Ukraine "About a transmission METAL-OXIDESEMICONDUCTOR plenary powers" from 06.02.2008 № 252-r. the Governmental courier(28).

President UA, .. (2001). Decree of the President of Ukraine: "About events in relation to the use of space technologies for innovative development of economy of the state" from February, 6 , 2001 №a 73/2001. Official announcer of Ukraine(6), 7.

Raizenberg, B., Lozovskiy, L., \& Starodubtseva, E. (2006). Modern economic dictionary (5th edition processed and complemented ed.). Infra-M. 
Resolution. (2000). Resolution of Cabinet of Ministers of Ukraine "About creation of the State innovative fund" : by the state on 13.04.2000 - article 674. Official announcer of Ukraine(16), 95.

Resolution. (2003). Resolution of Cabinet of Ministers of Ukraine "About claim of Order of state registration of innovative projects and conduct of the State register of innovative projects": by the state on 05.10.2004. Official announcer of Ukraine(38), 42.

Resolution. (2003). Resolution of Cabinet of Ministers of Ukraine "About events in relation to support of innovative-investment projects" : by the state on 15.05 .2003 - article 944. Official announcer of Ukraine(21), 413.

Resolution. (2004). Resolution of Cabinet of Ministers of Ukraine "About claim of Order of forming, examination and discussion of priority directions of innovative activity" : by the state on 13.07.2004 - article 1892. Official announcer of Ukraine, 1(28), 182.

Resolution. (2004). Resolution of Cabinet of Ministers of Ukraine "About claim of Order of grant of sponsorship to the subjects of innovative activity due to money of the state budget by reduction of prices of long-term credits" from 17.11.2004 №1563 - article 3048. Official annoucer of Ukraine, 68.

Resolution. (2004). Resolution of Cabinet of Ministers of Ukraine "About claim of Statute about the order of creation and functioning of technoparks and innovative structures of other types" by the state on 25.08.2004. Official announcer of Ukraine(34), 1.

Resolution. (2007). Resolution of Cabinet of Ministers of Ukraine "About claim of Order of realization of monitoring and realization of control after realization of projects of technological parks" from 21.03.2007 №517 - article 877. Official announcer of Ukraine(22), 49.

Resolution. (2007). Resolution of Cabinet of Ministers of Ukraine "About formation of the Ukrainian state innovative company": by the state on 08.08.2007 - article 2348. Official announcer of Ukraine(59), 23.

Resolution. (2007). Resolution of Cabinet of Ministers of Ukraine "Some questions of realization of Law of Ukraine "About government control of activity in the field of the transfer of technologies"'" from 01.08.2007 №995 - article 2306. Official announcer of Ukraine(58), 19.

Resolution. (2008). Resolution of Cabinet of Ministers of Ukraine "About claim of minimum rates of reward to the authors of technologies and persons that carry out their transfer" from 04.06.2008 №520 - article 1359. Official announcer of Ukraine, 33.

Resolution. (2009). Resolution of Cabinet of Ministers of Ukraine "About claim of Order of realization of state accreditation of physical and legal persons on realization on permanent and/or professional basis of intermediary activity in the field of the transfer of techn..". Official announcer of Ukraine(85), 37.

Sokolov, A. (2007). Forsite: look in the future. Forsite, 1(1), 8-15.

Sokolov, A. (2007). Method of critical technologies. Forsite, 4(4), 64-74.

Sukharev, A., \& Krutskih, V. (2002). Large legal dictionary (2nd edition - processed and complemented ed.). (A. Sukharev, \& V. Krutskih, Eds.) INFRA-m.

Tsyrat, A. V., \& Krivonos, E. A. (2004). Franchising from Z to A: Terminological dictionary. Kyiv: Association of franchising.

UA Gov, .. (2004, 01 06). Law of Ukraine "On scientific and technical information": article 181. Lists of Supreme soviet of Ukraine, 13.

UA Gov, .. (2004, 04 20). Law of Ukraine "On the National complex program of development of scientifically high-tech" . List of Supreme soviet of Ukraine(32), 384.

UA Gov, .. (2006, 02 09). A law of Ukraine "Law of Ukraine "On priority directions of development of scitech": article 199. Lists of Supreme soviet of Ukraine(22), 832. 
UA Gov, .. (2006). Law of Ukraine "On government control of activity in the field of the transfer of technologies" №1436 - V. List of Supreme soviet of Ukraine(45), 434.

UA Gov, .. (2006, 03 03). Law of Ukraine "On scientific and scientific and technical examination": article 199. Lists of Supreme soviet of Ukraine(22), 832.

UA Gov, .. (2006, 02 01). Law of Ukraine "On the dedicaded mode of innovative activity of technological parks": article 182. Lists of Supreme soviet of Ukraine(22), 809.

UA Gov, ... (2008, 12 18). Law of Ukraine "On priority directions of innovative activity in Ukraine": article 219. Lists of Supreme soviet of Ukraine(16), 562.

UA Gov, .. (2009). Civil Code of Ukraine : by the state on 10.12.2009. Official announcer of Ukraine(94).

UA Gov, .. (2009, 08 05). Commercial code of Ukraine: article 2065. The Official announcer of Ukraine(59), 20.

UA Gov, .. (2009). Law of Ukraine "On foreign economic activity": by the state on 23.06.2009 - article 1629. Official announcer of Ukraine(48), 42.

UA Gov, .. (2009, 01 14). Law of Ukraine "On investment activity": Article 257. List of Supreme soviet of Ukraine(19), 648.

UA017. (2009). Civil Code of Ukraine. Retrieved from WIPO Resources: http://www.wipo.int/wipolex/en/text.jsp?file_id=181865

Ward, S. (2012). Small Business: Canada. Retrieved from About.com: http://sbinfocanada.about.com/cs/startup/g/turnkey.htm

Received for publication: $\quad 22.10 .2012$

Revision received: $\quad 23.11 .2012$

Accepted for publication: $\quad 21.12 .2012$

\section{How to cite this article?}

Style - APA Sixth Edition:

Manylich, M. I., \& Likholet, S. I. (2013, 01 15). Forms and methods of technologies transfer adjusting in Ukraine. (Z. Čekerevac, Ed.) MEST Journal, 1(1), 137-146. Retrieved from

www.meste.org/mest/MEST 1 2013/ 14.pdf. doi:10.12709/mest.01.01.01.14.pdf

Style - Chicago Fifteenth Edition:

Manylich, Mychailo Ivanovich, and Sergei llyich. Likholet. "Forms and methods of technologies transfer adjusting in Ukraine." Edited by Zoran Čekerevac. MEST Journal (MESTE NGO) 1, no. 1 (01 2013): 137-146.

Style - GOST Name Sort:

Manylich Mychailo Ivanovich and Likholet Sergei llyich. Forms and methods of technologies transfer adjusting in Ukraine [Journal] = Adjusting of transfer of technologies in Ukraine // MEST Journal / ed. Čekerevac Zoran. - Belgrade - Toronto : MESTE NGO, 01 15, 2013. - 1 : Vol. 1. - pp. 137-146.

Style - Harvard Anglia:

Manylich, M. I. \& Likholet, S. I., 2013. Forms and methods of technologies transfer adjusting in Ukraine. MEST Journal, 15 01, 1(1), pp. 137-146.

Style - ISO 690 Numerical Reference:

Forms and methods of technologies transfer adjusting in Ukraine. Manylich, Mychailo Ivanovich and Likholet, Sergei Ilyich. [ed.] Zoran Čekerevac. 1, Belgrade - Toronto : MESTE NGO, 01 15, 2013, MEST Journal, Vol. 1, pp. 137-146. 